\title{
EVALUATION OF LEMON GRASS (Cymbopogon citraturs) OIL AS A GROWTH PROMOTER ON BROILER CHICKEN
}

\author{
M. R. Tiwari ${ }^{1}$, B. Shah ${ }^{2}$ and A. K. Jha ${ }^{3}$
}

\begin{abstract}
A study was carried out to evaluate the different levels of lemon grass oil as a growth promoter on the growth performance of broiler chicken at Regional Agriculture Research Station, Parwanipur, Bara from December 2017 to January 2018 for 36 days. A total of 180 day old chicks were procured from Shivam Hatchery Birgung. Control group $\left(T_{1}\right)$ was fed with concentrate feed without lemon grass oil inclusion whereas $T_{2}$, $T_{3}$ and $T_{4}$ groups were fed concentrate feed treated with lemon grass oil at the rate of 200,400 and $600 \mathrm{ml} / 100 \mathrm{~kg}$ feed, respectively. Experimental birds were provided ad libitum amount of starter feed from 0 to 21 days and finisher feed from 22 to 36 days twice a day. Feed intake was recorded daily and body weight gain was measured in 7 days interval. Experiment revealed that FCR was found highest in $T_{3}(1: 1.44 \mathrm{~kg})$ and lowest in $T_{4}(1: 1.51 \mathrm{~kg})$ which was also non-significant among diet groups. Similarly, the total weight gain of experimental bird was found higher in $T_{3}(2385.13 \mathrm{~g})$ followed by $T_{1}$ and $T_{2}$ (2279.46 and $2271.86 \mathrm{~g}$, respectively).
\end{abstract}

Keywords: Broiler, growth performance, lemon grass oil, Nepal

\section{INTRODUCTION}

About $68 \%$ of people in Nepal depend on agriculture for their livelihoods which contributes about 34\% of Total Gross Domestic Productions. Agriculture in Nepal is subsistent in nature and crops are mostly integrated with livestock. Livestock is one of the important sources of cash income for farm a household which contributes $29 \%$ of agriculture GDP and about $11.5 \%$ of total national GDP (MoAD, 2072/73).

Poultry meat is an important source of high quality protein, minerals and vitamins to balance the human diet. Broiler farming has several advantages: firstly the initial investment is low, and there is a faster return from the investment. Since, broilers have high feed conversion ratio, only a minimum amount of feed is required for per unit body weight gain in comparison to other

1 Nation Animal Science Research Institute (NASRI), Khumaltar, Lalitpur.

Corresponding author: Email: tiwari65@yahoo.com

2 Animal Nutrition Division, Khumaltar, Lalitpur

3 Regional Agriculture Research Station, Parwanipur, Bara 
livestock species. Demand of poultry meat is high compared to sheep and goat meats. The total population of poultry in Nepal is estimated to be about 68.63 million and producing $55041 \mathrm{mt}$. meats per annum (Krishi diary, 2017).

Due to increases in population, income and living standards, consumers' demand shifts to more poultry meat consumption. The poultry industry is presently studying on alternatives to meet these consumers' demands. Also, scientists are trying much more efforts to respond to these expectations. On the other hand, they want to make sure this does not decrease the quality of the end product or ignore animal welfare. Nowadays, increasing of consumer awareness for safety poultry products and from stable to table approach tended the consumers' preferences towards to healthy animals' products. Performance enhancers until recently called growth promoters are used to improve animal growth rate and/or feed conversion ratio. One of the feed additives used to increase the performance of poultry are herbs. These herbs are the dried leaves of aromatic plants, usually found without stems (Peter, 2012). In particular, with the ban on the use of antibiotics to increase growth, studies on plantbased alternatives have increased. Lemon grass contains flavonoids, phenolic compounds, terpenoids (Burkill, 1996) and essential oils (such as citral a, citral $B$, nerolgeraniol, citronellal, terpinolen e, geranyl acetate, myrecene and terpinolmethylheptenone) which may be responsible for its different biological activities such as antibacterial, antidiarrheal, antifungal, antioxidants, and as a growth promoter (Shah et al., 2011). There are few scientific studies on the use of lemon grass or its secondary metabolites for performance enhancing purposes in poultry, especially in broilers (Mmereole, 2010; Mukhtar et al., 2012; Thayalini et al., 2011), pigs (Tartrakoon et al., 2002) and rabbits (Omer et al., 2010). Mmereole (2010) and Mukhtaret al., (2012) reported that lemon grass could be an alternative to antibiotics.

According to the International Journal of Poultry Science, lemon grass oil (LGO) is considered as a viable alternative to antibiotics for the broiler and have been studied as alternative for microbial and growth promoting abilities in the poultry, and that resulted minimized feed expense in the production (Russo, 1992). Several studies carried out abroad showed that incorporating LGO in broiler diet as a supplement would stimulate the growth performance of broilers (Cross et al., 2002; Bampidis et al., 2005). Mukhtar et al. (2012) reported that broilers fed diets supplemented with different levels of LGO significantly consumed more feed and improved body weight gain compared to the control group.

In Nepal, there is a paucity of information regarding the use of LGO as a growth promoter. Keeping in view of the above facts, this study was designed to 
evaluate the effect of different level of LGO inclusion in broiler diet for growth promotion.

\section{MATERIALS AND METHODS}

\section{EXPERIMENTAL SITE AND BIRDS' MANAGEMENT}

The experiment was carried out on Cobb 500 broiler chickens at Regional Agricultural Research Station, Parwanipur, Bara from December 2017 to January 2018 to evaluate the effect of different level of LGO inclusion in diet as a natural growth promoter on the growth performance of broiler chicks. One hundred and eighty day old birds were procured from Shivam Hatchery, Birgung, Parsa and were allocated into four treatments with three replications having 15 birds in each replication by using Completely Randomized Design (CRD). All experimental birds were vaccinated with F1 vaccine at the rate of one drop to each bird against Ranikhet at the first week.

\section{DIET COMPOSITION}

Compound feed was procured from Shakti Feed Industry of Birgung, Parsa and treated with lemon grass oil at the rate of 200,400 and $600 \mathrm{ml} / 100 \mathrm{~kg}$ feed for $T_{2}, T_{3}$ and $T_{4}$, respectively. $T_{1}$ was as a control group. Lemon grass oil was procured from Herbs Production and Processing Plant of Ministry of Forest and Soil Conservation, Jadibuti, Kathmandu. The samples of treated and untreated feeds were brought to the Animal Nutrition Division, Khumaltar, Lalitpur for proximate analysis.

\section{CHEMICAL ANALYSIS}

Respective samples were analyzed for dry matter (DM), organic matter (OM), total ash (TA), crude protein (CP), crude fibre (CF) contents. The dry matter was determined by oven drying at $100^{\circ} \mathrm{C}$ for 24 hours. Crude protein was analyzed using the Kjeldahl method. Ash content was determined by ashing at $550^{\circ} \mathrm{C}$ in a muffle furnace for 16 hours (AOAC, 1980). Crude fibre of the samples was determined using the Van Soest method (Goering and Van Soest, 1970). 


\section{EXPERIMENTAL DIETS}

The following experimental diets were administrated to the birds as shown in Table 1.

Table 1: Experimental diets

\begin{tabular}{cl}
\hline Treatment & Diet \\
\hline 1 & Adlib concentrate feed without lemon grass oil \\
2 & $\begin{array}{l}\text { Adlib concentrate feed treated with lemon grass oil @ } 200 \mathrm{ml} / 100 \mathrm{~kg} \\
\text { feed }\end{array}$ \\
3 & $\begin{array}{l}\text { Adlib concentrate feed treated with lemon grass oil @ } 400 \mathrm{ml} / 100 \mathrm{~kg} \\
\text { feed } \\
4\end{array}$ \\
& $\begin{array}{l}\text { Adlib concentrate feed treated with lemon grass oil @ } 600 \mathrm{ml} / 100 \mathrm{~kg} \\
\text { feed }\end{array}$
\end{tabular}

\section{FEEDING SCHEDULE}

Concentrate mixture was given on group basis and provided to the experimental birds twice a day in the morning and evening in adlib amount for both periods (starter 0- 21 days and finisher 22-36 days). Clean drinking water was provided in adequate amount.

\section{OBSERVATION RECORDING}

The trial period was of 36 days. Quantity of concentrate mixture given daily to the birds in group weighed daily and refusal was weighed in the next morning. The body weight gain measurement was done in group basis (replication wise) in seven days interval in the morning before feeding.

\section{DATA ANALYSIS}

Data of feed intake and body weight gain was analyzed by One Way Annova test for every measurement using statistical package SPSS, Version 16. 


\section{RESULTS AND DISCUSSION}

\section{CHEMICAL COMPOSITION OF CONCENTRATE MIXTURE}

The chemical composition of feeds used in experiment is presented in Table 2.

Table 2: Chemical composition of the feeds (on DM basis)

\begin{tabular}{ccccccc}
\hline Treatment & DM & OM & TA & CP & CF & $\begin{array}{c}\text { Gross } \\
\text { energy, Kcal }\end{array}$ \\
\hline \multicolumn{7}{c}{ Starter feed (1-21 days) } \\
\hline 1 & 89.31 & 94.68 & 5.32 & 18.07 & 5.53 & \\
3 & 89.50 & 94.58 & 5.42 & 18.59 & 6.47 & \\
4 & 89.19 & 97.31 & 2.69 & 18.12 & 7.16 & \\
\hline \multicolumn{7}{c}{ Finisher feed (22-36 days) } \\
\hline 1 & 93.48 & 92.99 & 7.01 & 14.67 & 7.18 & \\
3 & 92.95 & 94.35 & 5.65 & 14.14 & 5.44 & \\
4 & 94.09 & 94.04 & 5.96 & 14.76 & 5.29 & \\
\hline Lemon & 93.6 & 93.63 & 6.37 & 14.41 & 7.43 & \\
grass oil & NA & NA & NA & 7.79 & NA & \multirow{2}{*}{$\mathbf{8 7 0 1 . 2 6}$} \\
\hline
\end{tabular}

FEED INTAKE

The average feed intake of experimental birds is given in Table 3.

Table 3: Feed intake of experimental birds, $g($ Mean \pm SD)

\begin{tabular}{ccccccccc}
\hline TRT & $\mathbf{O}$ day & $\mathbf{7}$ days & $\begin{array}{c}\mathbf{1 4} \\
\text { days }\end{array}$ & $\begin{array}{c}\mathbf{2 1} \\
\text { days }\end{array}$ & $\mathbf{2 8}$ days & $\mathbf{3 6}$ days & $\begin{array}{c}\text { Cumulative } \\
\text { feed intake, } \mathbf{g}\end{array}$ & FCR \\
\hline 1 & 5.44 & 40.08 & 77.82 & 125.24 & 165.46 & 176.93 & 3330.95 & 1.46 \\
& \pm 1.35 & \pm 1.08 & \pm 1.57 & \pm 3.37 & \pm 2.70 & \pm 1.02 & & \\
2 & 4.30 & 36.08 & 76.93 & 124.53 & 166.57 & 187.33 & 3354.04 & 1.47 \\
& \pm 0.33 & \pm 0.65 & \pm 2.20 & \pm 4.10 & \pm 3.24 & \pm 1.09 & & \\
3 & 4.70 & 39.02 & 76.30 & 123.11 & 168.39 & 199.82 & 3443.17 & 1.44 \\
& \pm 0.60 & \pm 0.90 & \pm 1.44 & \pm 6.22 & \pm 1.48 & \pm 1.32 & & \\
4 & 5.19 & 38.22 & 77.37 & 128.48 & 161.90 & 184.84 & 3377.33 & 1.51 \\
& \pm 0.70 & \pm 1.98 & \pm 1.42 & \pm 2.43 & \pm 7.06 & \pm 1.93 & & \\
\hline Mean & 4.91 & $\mathbf{3 8 . 3 5}$ & $\mathbf{7 7 . 1 0}$ & $\mathbf{1 2 5 . 3 4}$ & $\mathbf{1 6 5 . 5 8}$ & $\mathbf{1 8 7 . 2 3}$ & 3376.37 & 1.47 \\
& \pm 0.84 & \pm 1.87 & \pm 1.55 & \pm 4.18 & \pm 4.34 & \pm 1.46 & & \\
\hline $\mathrm{P}$ & $\mathrm{P}>0.05$ & $\mathrm{P}<0.05$ & $\mathrm{P}>0.05$ & $\mathrm{P}>0.05$ & $\mathrm{P}>0.05$ & $\mathrm{P}>0.05$ & $\mathrm{P}>0.05$ & $\mathrm{P}>0.05$ \\
Value & & & & & & & & \\
\hline
\end{tabular}

Table 3 showed that in the $7^{\text {th }}$ days of experiment, highest feed intake per bird was observed in $T_{1}(40.8 \mathrm{~g})$ followed by $T_{3}$ and $T_{4}(39.02 \mathrm{~g}$ and $38.22 \mathrm{~g}$, 
respectively) which was significant $(\mathrm{p}<0.05)$ among diet groups. In the $14^{\text {th }}$ days of experiment, feed intake per bird of $T_{1}$ and $T_{4}$, and $T_{2}$ and $T_{3}$ was almost similar (77.82g and $77.37 \mathrm{~g}$, respectively, and $76.93 \mathrm{~g}$ and $77.3 \mathrm{~g}$ respectively) which were non-significant among diet groups. In the $21^{\text {st }}$ days of experiment, highest feed intake per bird was noted in $T_{4}(128.48 \mathrm{~g})$ followed by $T_{1}$ and $T_{2}$ ( $125.24 \mathrm{~g}$ and $124.53 \mathrm{~g}$, respectively) which was also non-significant among diet groups. Similarly, in the $28^{\text {th }}$ days of experiment, highest feed intake per bird was observed in $T_{3}(168.39 \mathrm{~g})$ followed by $T_{2}$ and $T_{1}(166.57 \mathrm{~g}$ and $165.46 \mathrm{~g}$, respectively) which was non-significant among diet groups. Likewise, in the $36^{\text {th }}$ days of experiment, again highest feed intake per bird was found to be in $\mathrm{T}_{3}(199.82 \mathrm{~g})$ followed by $\mathrm{T}_{2}$ and $\mathrm{T}_{4}(187.33 \mathrm{~g}$ and $184.84 \mathrm{~g}$, respectively), however, it was non-significant among diet groups. The cumulative feed intake per bird was found higher in $\mathrm{T}_{3}(3443.17 \mathrm{~g})$ followed by $\mathrm{T}_{4}$ and $\mathrm{T}_{2}(3377.33 \mathrm{~g}$ and $3354.04 \mathrm{~g}$, respectively) which was also non-significant among diet groups. The FCR was highest in $T_{3}(1: 1.44 \mathrm{~kg})$ and lowest in $T_{4}(1: 1.51 \mathrm{~kg})$ which also nonsignificant among diet groups.

\section{BODY WEIGHT GAIN}

The average growth performance of experimental birds in given in Table 4 .

Table 4: Weight gain of experimental birds, g (Mean \pm SD)

\begin{tabular}{cccccccccc}
\hline TRT & $\begin{array}{c}\text { Initial } \\
\text { weight }\end{array}$ & $\mathbf{7}$ days & $\mathbf{1 4}$ days & $\mathbf{2 1}$ days & $\mathbf{2 8}$ days & $\mathbf{3 6}$ days & $\begin{array}{c}\text { Total weight } \\
\text { gain, } \mathrm{g}\end{array}$ & ADG \\
\hline 1 & 44.97 & 177.77 & 471.1 & 1033.0 & 1677.77 & 2324.0 & 2279.46 & 63.31 \\
& \pm 1.03 & \pm 10.18 & \pm 23.41 & \pm 35.27 & \pm 21.42 & \pm 1.01 & \pm 101.36 & \pm 2.81 \\
2 & 43.64 & 171.10 & 479.99 & 984.44 & 1577.77 & 2316.0 & 2271.86 & 63.10 \\
& \pm 0.75 & \pm 3.85 & \pm 17.63 & \pm 36.71 & \pm 86.75 & \pm 83.35 & \pm 82.61 & \pm 2.29 \\
3 & 45.99 & 182.22 & 486.66 & 997.77 & 1606.66 & 2431.0 & 2385.13 & 66.25 \\
& \pm 1.96 & \pm 3.84 & \pm 24.03 & \pm 63.36 & \pm 141.10 & \pm 1.24 & \pm 126.01 & \pm 3.50 \\
4 & 44.22 & 175.55 & 482.21 & 986.66 & 1688.88 & 2273.0 & 2229.10 & 61.85 \\
& \pm 1.23 & \pm 3.85 & \pm 26.94 & \pm 80.82 & \pm 16.77 & \pm 6.67 & \pm 7.10 & \pm 0.24 \\
\hline Mean & 44.70 & 176.66 & 479.99 & 1001.0 & 1637.77 & 2336.0 & 2291.39 & 62.62 \\
& \pm 1.45 & \pm 6.66 & \pm 20.69 & \pm 52.98 & \pm 86.70 & \pm 98.20 & \pm 97.99 & \pm 2.73 \\
\hline \multirow{2}{*}{$\mathrm{P}$} & $\mathrm{P}>0.05$ & $\mathrm{P}>0.05$ & $\mathrm{P}>0.05$ & $\mathrm{P}>0.05$ & $\mathrm{P}>0.05$ & $\mathrm{P}>0.05$ & $\mathrm{P}>0.05$ & $\mathrm{P}>0.05$ \\
Value & & & & & & & & \\
\hline
\end{tabular}


Table 4 showed that highest body weight of bird in the $7^{\text {th }}$ day of experiment was observed in $T_{3}(182.22 \mathrm{~g})$ followed by $T_{1}$ and $T_{4}(177.77$ and $175.55 \mathrm{~g}$, respectively). In the $14^{\text {th }}$ day of experiment, again highest body weight was monitored in $T_{3}(486.66 \mathrm{~g})$ followed by $\mathrm{T}_{4}$ and $\mathrm{T}_{2}(482.21$ and $479.99 \mathrm{~g}$, respectively). In the $21^{\text {st }}$ day of experiment, higher body weight was found in $\mathrm{T}_{1}(1033 \mathrm{~g})$ followed by $\mathrm{T}_{3}$ and $\mathrm{T}_{4}(997.77$ and $986.66 \mathrm{~g}$, respectively). Similarly, in the $28^{\text {th }}$ day of experiment, bird of $\mathrm{T}_{4}$ weighed higher $(1688 \mathrm{~g})$ than that of $T_{3}$ and $T_{1}$ (1606.66 and $1677.77 \mathrm{~g}$, respectively). Likewise, by the end of experiment at $36^{\text {th }}$ days, higher weight was found in the $T_{3}(2431 \mathrm{~g})$ followed by $T_{1}$ and $T_{2}$ (2324 and $2316 \mathrm{~g}$, respectively). Inclusion of LOG did not affect significantly on body weight gain during experiment period from initial to end of the experiment for 36 days (Fig.1). The total weight gain of experimental bird was found to be higher in $T_{3}(2385.13 \mathrm{~g})$ followed by $T_{1}$ and $T_{2}(2279.46$ and $2271.86 \mathrm{~g}$, respectively). Average daily gain of experimental birds noted higher in $T_{3}(66.25 \mathrm{~g})$ followed by $T_{1}$ and $T_{2}(63.31$ and $63.1 \mathrm{~g}$, respectively).

Figure 1. Body weight gain trend of experimental birds

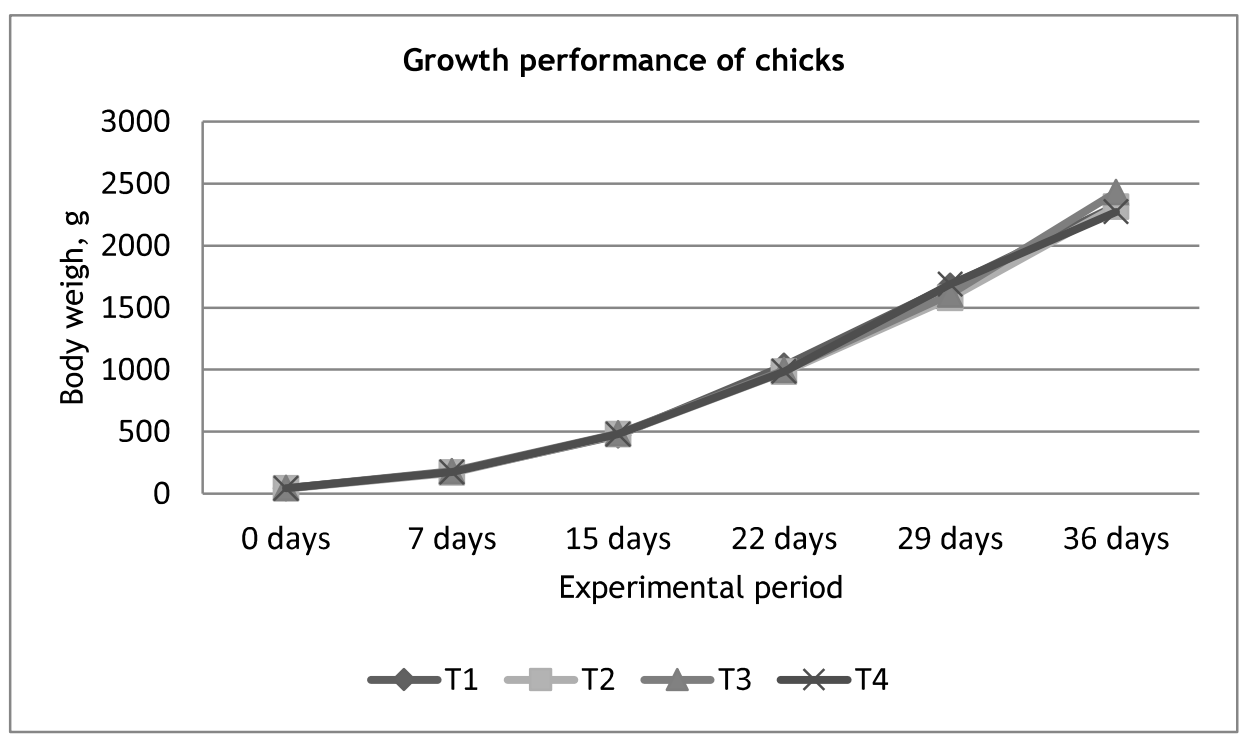

According to the various literatures, body weight gain and feed intake of experimental birds is correlated with addition of LGO in feed but experiment did not reveal that in our experiment, however, an assumption was taken. Our experiment revealed that broilers fed diets treated with $600 \mathrm{ml} / 100 \mathrm{~kg}$ feed had less feed intake (3377.33g) than that of $400 \mathrm{ml} / 100 \mathrm{~kg}$ feed $(3442.17 \mathrm{~g})$ which was statistically non-significant. These findings were in agreed with Alciceket al., (2004). 
Similarly, experiment revealed that the body weight gain was also higher ( $2385.13 \mathrm{~g}$ ) in $\mathrm{T}_{3}$ where LGO was included $400 \mathrm{ml} / 100 \mathrm{~kg}$ feed compared to the control group (2279.46 g). This result was in the line of Tekeli (2011), where he noted that chicks fed on diet with supplemented LGO recorded significantly heavy weight gain, This improve may be attributed to the increase in total feed consumption, the active compounds, antimicrobial and antioxidant activities of the LGO. These results are in agree with Tekeli (2011) and Mukhtar (2011) where their experiment revealed significantly improve in feed conversion ratio for broilers fed diets supplemented with various levels of LGO compared with control group.

Khattak et al., (2014) reported that the inclusion of lemon grass in the broiler diet improves the body weight gain with positive effects on feed conversion ratio. Mukhtar et al., (2012) reported that 50, 100 and $150 \mathrm{ml} / \mathrm{kg}$ feed supplementation of lemon grass oil in broiler diets increased feed consumption.

Mmereole (2010) conducted an experiment to evaluate the effects of dietary inclusion of lemon grass leaf meal (LGLM) on growth performances of broiler chickens and its ability to be utilized as a viable alternative to antibiotic growth promoters. The experiment involved two hundred and seventy day-old Aboracre broiler chickens randomly separated into 3 experimental diet groups, with each being replicated 3 times. Ninety day-old birds were randomly allocated into three groups and each group had 30 replicate. The diet groups were: $T_{1}$ : control (basal diet), $T_{2}$ : basal diet $+1 \%$ LGLM and $T_{3}$ : basal diet $+1 \%$ Teramycin antibiotic growth promoter. The results obtained indicated that the performances of the birds placed on control diet $\left(T_{1}\right)$ were significantly $(p<0.05)$ lower in all parameters than those placed on $T_{2}$ and $T_{3}$. The results further indicated that final body weight of the birds on $T_{2}(1895.56 \mathrm{~g})$ was quantitatively higher than that of the birds in $T_{3}(1875.92 \mathrm{~g})$, the difference was not significant. With respect to feed intake and feed conversion ratio, it was observed that there were no significant differences between the birds in $\mathrm{T}_{2}$ and $\mathrm{T}_{3}$.

Mukhtar et al., (2012) conducted an experiment on broiler chicks for 42 days formulating five experimental diets (A, B, C, D and E). Diets $A$ was control, diet B was supplemented with antibiotic (Neomycin $16 \mathrm{mg} / \mathrm{kg}$ ) while diets C, D and E were supplemented with (LGO) at 50,100 and $150 \mathrm{mg} / \mathrm{kg}$, respectively. Result obtained showed that addition of LGO significantly improved $(p<0.05)$ body weight gain, feed intake and feed conversion ratio of broiler chicks as compared to the control group. Non-significant differences were noted among broilers fed on diets supplemented with LGO and antibiotic supplemented groups, respectively. Results revealed non-significant differences among all 
treatment groups regarding carcass dressing percentages giblet, commercial cuts (breast, drumstick and thigh) and percentage of their separable tissue, meat chemical composition and subjective meat quality parameters. Economically the addition of LGO improved the performance of broiler chicks and resulted in economic benefits. Moreover, this study showed that LGO when added as a growth promoter in broiler diets had a similar effect as that with antibiotic without any adverse effects.

Tiwari et al., (2017) conducted an experiment on broiler chicken and reported that inclusion of LGO at the rate of $400 \mathrm{ml} / 100 \mathrm{~kg}$ feed improved the weight gain, reduced birds mortality and reduced the period of broiler harvesting.

\section{CONCLUSION}

Inclusion of lemon grass oil as a growth promoter in broiler diet is one of the option to enhance the production performance of broiler chicken. Inclusion of lemon grass oil at the rate of $400 \mathrm{ml} / 100 \mathrm{~kg}$ feed had beneficial effect than that of 200 and $600 \mathrm{ml} / 100 \mathrm{~kg}$ feed, however, cost benefit analysis should be carried out. Therefore, further study is suggested to ascertain the cost of production.

\section{ACKNOWLEDGEMENT}

Authors are too grateful to Nepal Agricultural Research Council (NARC) for fund allocation for this research work. Similarly, help and coordination provided by Regional Director of RARS, Parwanipur, Mr Tufel Aftar also deserved for high appreciation. Likewise, authors are also thankful to Mr Dilip Sah (Technical Officer) and Narayan Das (animal attendant) for their pain stocking work in data recording, feeding and housing management. The authors are also expressed their gratitude to the all scientific, technical, admin and finance staff of Animal Nutrition Division for being helping hand during entire trial period. 
The Journal of Agriculture and Environment Volume: 20, June, 2019

\section{REFERENCES}

AOAC, 1980. Official methods of analysis of the Association of Official Analytical Chemists, 17th ed., Inc., Arlington, Verginia, USA.

Alcicek, I.M., M. Bozkurt and M. Cabuk, 2004. The effect of a mixture of herbal essential oils on organic acid or a probiotic on broiler performance. South African Society of Animal Science 34 (4): 217-222.

Burkill, H. M., 1996. The useful plants of West Tropical Africa. Vol 3, Families J-L, Royal Botanic Gardens, Kew Publishing, 2nd ed.: pp.29-30. United Kingdom.

Bampidis, V.A., V. Christodoulou, P. Florou-Paneri, E. Christaki, P.S. Chatzopoulou,T.Tsiligianni and A.B.Spais, 2005. Effect of dietary dried Oregano leaves on growth performance, carcass characteristics and serum cholesterol of female early maturing Turkey. British Journal of Poultry Science 46: 595-601.

Cross, D.E., T. Acamovic, S.G.Deans and R.M.Cdevitt, 2002. The effects of dietary inclusion of herbs and their volatile oils on the performance of growing chickens. British Journal of Poultry Science 43: 33-35.

Goering, H.K. and Van, Soest, 1970. Forage fibre analysis apparatus, reagents, procedures and some application, ARS, USDA.

Khattak, F., A. Ronchi,P. Castelli and N. Sparks, 2014. Effect of natural blend of essential oil on growth performance, blood biochemistry, cacal morphology and carcass quality of broiler chickens. Poultry Science 93: 132-137.

Krishi diary. 2017. Agriculture Information and Communication Center. Ministry of Agriculture Development. Singh Durbar, Kathmandu, Nepal.

MoAD.2072/73. Statistical Information on Nepalese Agriculture. Ministry of Agriculture Development. Singh Durbar, Kathmandu, Nepal.

Mukhtar, A.M., K.A. Mohammad, O.A. Amal and A.H. Ahlam, 2012. Effect of different level of lemon grass oil as a natural growth promoter on the performance, carcass yields and serum chemistry of broiler chicks. Egyptian Poultry Science 33 (1): 17.

Mukhtar, A.M., 2011. The effect of feeding clove oil on broiler performance. Australian Journal of Basic Science 5 (7): 49-51.

Mmereole, F.U.C. 2010. Effect of lemon grass leaf meal feed supplement on growth performance of broiler chicks. International Journal of Poultry Science 9 (12): 1107-1111.

Omer, H.A.A., H.M.H. Elallawy, L.D. AbdEl-Samee and N. Maghraby, 2010. Productive performance of rabbits fed diets containing lemongrass or active dry yeast. 
American-Eurasian Journal of Agriculture and Environmental Science 7 (2): 179 187.

Shah, G., R. Shri, V. Panchal, N. Sharma, B. Singh and A.S. Mann, 2011. Scientific basis for the therapeutic use of Lemon grass. Journal of Advanced Pharmaceutical Technology \& Research 2(1): 3-8.

Tekeli, A., H.R. H.R. Kutla and L. Colic, 2011. Effect of Z. officinal and propalis extracts on the performance of broiler chicks. Current Research in Poultry Science 7: 441451.

Thayalini, K., S. Shanmugavelu, P.M. Saminathan, M.S. SitiMasidayu, Y. Nor Idayusni,H. C. ZainUddin,A. NurulAkmaland H.K. Wong, 2011. Effects of Cymbopogoncitratus leaf and Zingiberofficinale rhizome supplementation on growth performance, ileal morphology and lactic acid concentration in broilers. Malaysian Journal of Animal Science 14:43-49.

Tartrakoon, W., K. Wuthijaree, T. Vearasilp and U. Meulen, 2002. Use of lemon grass oil as feed additive in weanling pig diets. Conference on International Agricultural Research for Development. DeutscherTropentag, Witzenhausen, October 9-11, 2002.

Tiwari, M.R., B. Sah,A.K. Jha and M.P. Sah, 2017. Lemon grass oil feeding in relation to growth and carcass characteristics of broiler chicken. Nepalese Journal of Agricultural Sciences 15: 67-74. 